\title{
PELATIHAN PENILAIAN STATUS GIZI PADA GURU DALAM RANGKA DETEKSI SISWA STUNTING DI SEKOLAH DASAR
}

\author{
Linda Riski Sefrina, dan Milliyantri Elvandari \\ Universitas Singaperbangsa Karawang \\ E-mail: lindariski@gmail.com
}

\begin{abstract}
ABSTRAK. Pembangunan suatu negara dimulai dengan meningkatkan kualitas sumber daya manusia. Status gizi anak usia sekolah adalah status kesehatan yang perlu mendapat perhatian. Prevalensi stunting di Indonesia telah meningkat sejak 2010. Stunting adalah akibat tidak dapat dipulihkan dari kekurangan gizi kronis. Anak-anak usia sekolah yang mengalami stunting cenderung sering absen di kelas, mengalami ketidakmampuan belajar dan kinerja sekolah yang lebih rendah. Sasaran dari kegiatan ini adalah untuk meningkatkan keterampilan penilaian gizi guru sekolah dasar. Kegiatan pengabdian masyarakat ini terdiri dari penyuluhan dan pelatihan masyarakat untuk guru sekolah dasar. Pelatihan ini juga menggunakan alat yang disebut "Cakram Gizi" yang mudah digunakan. Mereka diberikan penyuluhan dan pelatihan dengan metode demonstrasi. Hasil dari kegiatan ini adalah bahwa penyuluhan meningkatkan pengetahuan guru tentang stunting. Selain itu, kegiatan pelatihan dapat meningkatkanpengetahuan guru tentang gizi pada anak sekolah dan dapat melakukan deteksi dini tentang gizi yang kurang pada siswa. . Berdasarkan layanan masyarakat ini, kami menyarankan bahwa program kesehatan masyarakat melibatkan institusi pendidikan, khususnya sekolah dalam menangani stunting.
\end{abstract}

Kata kunci: siswa; stunting; guru; pengetahuan; penilaian gizi

\section{NUTRITIONAL STATUS ASSESSMENT TRAINING IN TEACHERS IN THE DETECTION OF STUNTING STUDENTS IN ELEMENTARY SCHOOLS}

\begin{abstract}
A country development begins with improving the quality of human resources. The nutritional status of schoolage children was the one of health indicatosr that needed attention. The prevalence of stunting in Indonesia has increased since 2010. Stunting was an irreversible result of a chronic of nutrients deficiencies. The school-age children who experienced stunting tend to be often absent in class, experience learning disabilities and lower school performance. The target of this activity was to improve stunting knowledge and nutritional assessment skills of elementary school teachers. This community service activity was consist of community counseling and training for elementary school teachers. The training also used a tool called "Cakram Gizi" which was easily to be used. They were given through lecture and training or demonstration methods. The results of these activities were that community counseling increased teacher knowledge about stunting. In addition, training activities can improve teacher skills in assessing the nutritional status of students. Based on this community services, we suggest that the public health program involve educational institutions, escpecially the schools in dealing with stunting.
\end{abstract}

Key words: student; stunting; teacher; knowledge; nutritional assessment

\section{PENDAHULUAN}

Pembangunan yang kokoh dimulai dengan peningkatan kualitas sumber daya manusia. Dalam rangka mempersiapkannya, harus dimulai sejak dini termasuk pada usia sekolah termasuk anak SD. Anak SD sedang mengalami pertumbuhan secara fisik dan mental yang sangat diperlukan untuk menunjang kehidupannya di masa mendatang (Ningsih, 2016).

Status gizi anak usia sekolah merupakan salah satu indikator kesehatan yang perlu menjadi perhatian. Saat ini angka kekurangan gizi pada usia ini masih menjadi masalah, hal ini terbukti dari tingginya prevalensi stunting di Indonesia. Stunting merupakan suatu kondisi yang mencerminkan pertumbuhan seorang anak yang kurang optimal. Seorang anak dikategorikan menderita stunting berdasarkan indeks Panjang Badan menurut Umur $(\mathrm{PB} / \mathrm{U})$ atau Tinggi Badan menurut Umur (TB/U) dengan ambang batas (z-score) antara -3 SD sampai dengan < -2 SD. Stunting merupakan hasil yang irreversible dari kekurangan asupan zat gizi secara kronis dan akibat infeksi berulang selama periode emas kehidupan, 1000
HPK (Hari Pertama Kehidupan) (Kemenkes, 2011).

Di Indonesia, prevalensi yang cukup tinggi pada anak yang menderita stunting berdasarkan hasil Riset Kesehatan Dasar pada tahun 2010, prevalensi stunting pada anak usia sekolah di tingkat nasional yaitu sebesar $35,6 \%$, yang terdiri dari $15,1 \%$ anak dengan status gizi sangat pendek dan 20,5\% anak dengan status gizi pendek. Di Provinsi Jawa Barat, pada anak berusia > 6 tahun, prevalensi anak sangat pendek sebesar 13,9\% dan anak pendek sebesar 20,3\%. Prevalensi tersebut hampir mendekati dari angka prevalensi anak stunting di Indonesia (Balitbangkes, 2010).

Penelitian telah membuktikan bahwa anak stunting memiliki beberapa dampak pada kesehatan maupun selain kesehatan. Stunting memiliki dampak yang bersifat bersifat jangka panjang pada tingkat individu maupun masyarakat, seperti perkembangan fisik dan kognitif yang kurang optimal, menurunkan kapasitas produktifitas dan derajat kesehatan, serta peningkatan resiko penyakit degeneratif seperti diabetes (Walker et al., 2007).

Pada usia sekolah, anak sedang dalam masa pertumbuhan yang cepat, pengaturan konsumsi makanan 
sangat berperan dalam menjamin kecukupan asupan gizi sesuai kebutuhannya. Stunting berpotensi untuk menurunkan imunitas seorang anak (Rytter, 2014)). Hal tersebut menyebabkan Anak Usia Sekolah (AUS) yang mengalami stunting cenderung sering absen di kelas, mengalami gangguan belajar dan prestasi di sekolah yang lebih rendah daripada mereka yang tidak stunting (Picauly, 2013).

World Health Organization (WHO) telah menentukan target penurunan $40 \%$ prevalensi stunting pada balita di seluruh dunia pada tahun 2025. Dalam rangka mencapai tujuan tersebut, tindakan pertama yang dilakukan adalah memperbaiki identifikasi, pengukuran dan pengetahuan tentang stunting (WHO, 2014).

Sekolah merupakan suatu wadah di bidang pendidikan yang dapat memberikan pengetahuan, keterampilan dan pengalaman dalam rangka meningkatkan taraf kehidupan seseorang, termasuk kesehatan. Tahapantahapan penanganan stunting tidak dapat hanya dilakukan oleh satu pihak saja. Kerjasama banyak pihak perlu dilakukan untuk menurunkan prevalensi stunting serta mengurangi dampak stunting pada anak melalui program gizi sensitif dan spesifik (WHO, 2014). Selama ini, masih sedikit penanganan stunting yang melibatkan sumber daya dari dunia pendidikan, terutama guru sekolah. Guru sangat berperan dalam menyalurkan pengetahuan dan pemahaman pada siswa sekolah dasar, yang nantinya akan menghasilkan sikap dan perilaku siswa menjadi lebih baik.

Masalah gizi pada usia sekolah dapat menyebabkan rendahnya kualiatas tingkat pendidikan, tingginya angka absensi dan tingginya angka putus sekolah. Kekurangan gizi pada usia sekolah akan mengakibatkan anak menjadi lemah, cepat lelah dan mudah sakit. Oleh karena itu siswa seringkali absen serta mengalami kesulitan dalam mengikuti dan memahami pelajaran. Keadaan ini dapat menghambat pembentukan SDM yang sehat dan produktif untuk menghadapi era globalisasi.

Salah satu metode yang baik dan mudah dalam mengetahui status gizi siswa adalah pengukurantinggi badan. Oleh karena itu, penilaian dan pemantauan status gizi pada anak, terutama siswa yang baru masuk sekolah penting dilakukan sebagai deteksi siswa stunting.

Berdasarkan kunjungan dan observasi awal yang dilakukan, diperoleh beberapa informasi penting. Selama ini guru telah melakukan pengukuran tinggi badan dan berat badan dengan alat seadanya, namun tidak memahami interpretasi atas data tinggi badan dan berat badan tersebut. Hal ini kemungkinan dipengaruhi oleh belum adanya kunjungan, penyuluhan maupun pelatihan dari tenaga kesehatan terkait penilaian status gizi maupun tentang stunting.

Pengabdian masyarakat ini diharapkan mampu meningkatkan pengetahuan tentang stunting dan keterampilan daalam menentukan siswa yang stunting maupun yang tidak stunting oleh para Guru SD. Target dari kegiatan ini adalah peningkatan pengetahuan tentang gizi pada anak sekolah dan deteksi dini stunting pada Guru SD.

\section{METODE}

Kegiatan Pengabdian Masyarakat dilakukan di SDN Karawang Wetan 01 pada bulan Juli 2019. Kegiatan pengabdian masyarakat ini berupa penyuluhan dan pelatihan kepada Guru SD. Materi penyuluhan yang diberikan antara lain definisi, penyebab, dan dampak stunting pada anak. Selain itu diberikan pula contoh Menu Gizi Seimbang yang dapat digunakan untuk menurunkan resiko anak stunting. Setelah kegiatan penyuluhan diberikan, dilanjutkan dengan kegiatan Pelatihan Penilaian Status Gizi yang diberikan melaui metode ceramah dan latihan atau demonstrasi. Kegiatan pelatihan yang diberikan berisi materi tetang tata cara menentukan usia anak dan mengukur tinggi badan anak sesuai ketentuan dalam ). Selain itu, diberikan juga cara interpretasi hasil pengukuran tinggi badan siswa menurut usianya, untuk selajutnya dapat dikelompokkan menjadi stunting atau tidak stunting. Interpretasi tersebut menggunakan alat Cakram Cek Gizi Anak untuk Anak Usia 6-12 tahun Cakram Gizi merupakan suatu alat yang diciptakan oleh Pergizi Pangan. Kelebihan dari alat ini adalah mudah untuk digunakan dan dimengerti oleh masyarakat umum dalam rangka menentukan status gizi.

Teknik pengumpulan data dilakukan menggunakan instrumen kuesioner pre-test dan post-test. Sebelum dilakukan pelaksanaan kegiatan pengabdian, terlebih dahulu dilakukan pre-test, meliputi pengetahuan stunting dan keterampilan penilaian status gizi. Pre-test dilakukan sebelum penyuluhan yang dilakukan dengan metode wawancara terpimpin (dengan bantuan kuesioner) pada guru, dengan cara dipimpin langsung oleh pengabdi. Komponen yang dinyatakan dalam kuesioner anta ralin adalah mengenai definisi stunting, dampak stunting, dan cara menentukan anak stunting. Data keterampilan guru dikumpulkan dengan cara meminta guru untuk mendemontrasikan langkah-langkah penilaian status gizi siswa (menentukan usia anak dan mengukur tinggi badan siswa) sesuai dengan tata cara pengukuran yang sesuai buku Gibson (2005). Demonstrasi tersebut dilaksanakan oleh guru langsung pada siswa Kelas 1 Tahun Pelajaran 2019/2020.

Pada komponen pengetahuan maupun keterampilan masing-masing menggunakan 10 pertanyaan, apabila jawaban benar diberi nilai 1 dan jawaban salah diberi nilai 0 . Pengetahuan dikategorikan menjadi 3 tingkat, yang terdiri dari rendah (benar $<60 \%$ ), sedang $(60-80 \%$ ) dan baik (>80\%) (Khomsan, 2008). Keterampilan dikategorikan menjadi 2 jenis, yaitu baik (benar $\geq 80 \%$ ) dan kurang baik $(<80 \%)$ (Laraeni, 2014).

\section{HASIL DAN PEMBAHASAN}

Analisis data pengetahuan dan keterampilan penilaian status gizi dilakukan dengan menggunakan software 
Ms. Excel 2016. Analisis data pada kegiatan ini termasuk analisis deskriptif. Penyajian data hasil analisis disajikan dalam grafik dan persentase.

SDN Karawang Wetan 01 mempunyai 30 guru. Kegiatan Pengabdian Masyarakat ini hanya dihadiri 17 guru $(56,6 \%)$ karena terdapat beberapa guru yang berhalangan hadir. Penyuluhan yang dilakukan menggunakan metode ceramah diselingi dengan sesi diskusi.

Berdasarkan hasil analisis data pre-test dan posttest, terdapat peningkatan pengetahuan dan keterampilan setelah diberikan penyuluhan dan pelatihan. Gambar 3 menunjukkan bahwa terdapat peningkatan pengetahuan guru tentang stunting. Sebelum pelaksanaan, tidak ada guru yang termasuk dalam kategori pengetahuan baik tentang stunting, sebagian besar $(94,1 \%)$ masih memiliki pengetahuan yang rendah tentang stunting. Kemudian setelah diberikan penyuluhan terdapat perubahan, yaitu sebagian besar guru $(70,6 \%)$ memiliki pengetahuan yang baik tentang stunting.

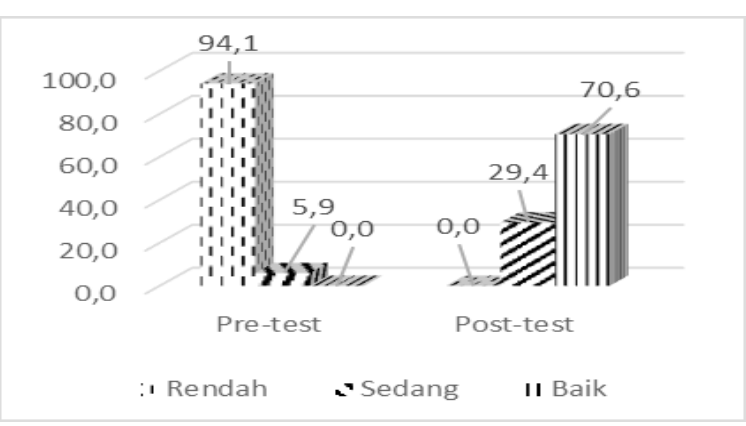

Gambar 3. Perbandingan Pengetahuan Stunting Guru berdasarkan Pre-test dan Post-test

Perilaku baru atau adopsi perilaku yang didasari pengetahuan cenderung lebih langgeng (long lasting) dibandingkan dengan yang tidak didasari pengetahuan (Notoatmodjo, 2010). Perubahan pengetahuan dapat dilakukan melalui intervensi edukasi termasuk penyuluhan (Suryawan dkk, 2019). Peningkatan pengetahuan guru ini diharapkan dapat merubah sikap dan perilaku guru, yang selanjutnya dapat disebarkan kepada siswa dan orang tua siswa.

Begitu pula dengan keterampilan guru, terdapat peningkatan keterampilan guru dalam menilai status gizi anak. Gambar 4 menunjukkan bahwa sebelum diberikan pelatihan, tidak ada satupun guru yang dapat menilai status gizi anak dengan benar. Setelah diberikan pelatihan, sebagian besar guru memiliki keterampilan yang baik.

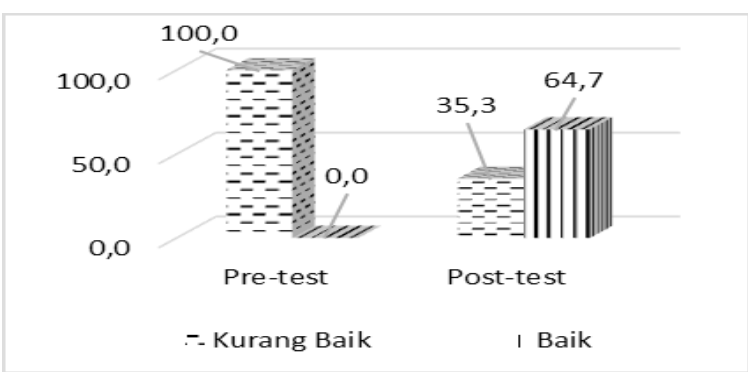

Gambar 4. Perbandingan Keterampilan Guru berdasarkan pre-test dan post-test
Hasil penilaian status gizi yang telah dilakukan oleh guru kepada siswa Kelas 1 disajikan dalam Tabel 1. Tabel 1 menunjukkan bahwa hanya 1 siswa yang tergolong ke dalam kategori stunting. Stunting merupakan hasil dari kekurangan zat gizi kronis.

Tabel 1. Hasil Penilaian Status Gizi Siswa

\begin{tabular}{cccc}
\hline \multirow{2}{*}{ Jenis Kelamin } & \multicolumn{2}{c}{ Stunting $[\mathrm{n}(\%)]$} & \multirow{2}{*}{ Jumlah } \\
\cline { 2 - 3 } & Ya & Tidak & \\
\hline Laki-laki & $1(100,0)$ & $38(50,0)$ & $39(50,6)$ \\
Perempuan & $0(0,0)$ & $38(50,0)$ & $38(49,4)$ \\
Jumlah & $1(100,0)$ & $76(100,0)$ & $77(100,0)$ \\
\hline
\end{tabular}

Tabel 1 menunjukkan bahwa persentase stunting pada laki-laki lebih besar daripada laki-laki. Hal tersebut sejalan dengan RISKESDAS 2010 yang menunjukkan persentase anak pendek lebih besar pada anak laki-laki daripada anak perempuan (Balitbangkes, 2010).

Pada kegiatan pengabdian ini terdapat kesulitan pelaksanaan kegiatan. Tidak adanya ruang serbaguna yang dapat menampung semua guru, sehingga pelaksanaan kegiatan ini dilaksanakan di ruang guru. Letak ruang guru diantara ruang kelas membuat pelaksanaan kegiatan kurang kondusif dan sedikit terganggu oleh suasana ramai dari siswa SD yang berada di luar ruang guru. Hal tersebut dapat diatasi oleh perwakilan guru sehingga dapat dikendalikan.

Kegiatan penyuluhan stunting dan pelatihan penilaian status gizi ini telah mencapai fokus utama, yaitu meningkatkan pengetahuan stunting dan keterampilan guru dalam menilai status gizi anak. Selain materi penyuluhan yang berisi teori stunting, diberikan pula beberapa menu hidangan sesuai gizi seimbang yang dapat dibuat dalam kehidupan sehari-hari. Selain itu, penggunaan Cakram Gizi untuk usia 6-12 tahun sangat membantu para guru untuk dapat menilai siswa termasuk stunting atau tidak stunting.

Stunting merupakan gangguan kesehatan yang tergolong kronis dan membutuhkan penanganan komprehensif dari berbagai pihak. Anak yang stunting memiliki gangguan pertumbuhan fisik dan otaknya. Anak yang stunting cenderung tidak aktif jika di dalam kelas dan kurang produktif dibandingkan dengan anak yang tidak stunting. Dampak jangka panjang apabila hal ini tidak segera ditangani adalah penurunan kualitas Sumber Daya Manusia (SDM) (Megawati, 2019). Oleh karena itu, kegiatan penanggulangan stunting dengan melibatkan pihak sekolah penting dilakukan.

\section{SIMPULAN}

Berdasarkan kegiatan pengabdian masyarakat ini dapat disimpulkan bahwa kegiatan penyuluhan dapat meningkatkan pengetahuan guru tentang stunting. Selain itu, kegiatan pelatihan dapat meningkatkan keterampilan guru dalam menilai status gizi siswa. 
Ketercapaian program kesehatan masyarakat dipengaruhi oleh kerjasama dari berbagai pihak. Peningkatan peran guru salam program kesehatan Anak Usia Sekolah perlu menjadi perhatian. Sehingga hasil kegiatan PKM ini diharapkan dapat menjadi salah satu langkah alternatif yang dapat dilakukan untuk mengurangi prevalensi stunting serta meminimalisir dampak stunting pada siswa SD.

\section{DAFTAR PUSTAKA}

Gibson. 2005. Principles of Nutritional Assessment, 2nd ed. Oxford University Press, Oxford .

Kemenkes. 2011. Keputusan Menteri Kesehatan Republik Indonesia No: 1995/ Menkes/SK/XII/2010. Jakarta: Kementerian Kesehatan Republik Indonesia.

Laraeni Y, Wiratni A. 2014. Pengaruh Penyegaran Kader Terhadap Pengetahuan dan Keterampilan Kader Posyandu Menggunakan Dacin di Wilayah Kerja Puskesmas Dasan Cermen Kecamatan Sandubaya Kota Mataram. Media Bina Ilmiah. 8, 4, 44-52.

Megawati G, Wiramihardja S. 2019. Peningkatan Kapasitas Kader Posyandu dalam Mendeteksi dan Mencegah Stunting di Desa Cipacing Jatinangor. Dharmakarya, 8, (3), doi: 10.24198/dharmakarya. v8i3.20726.
Notoatmodjo, S. 2010. Promosi Kesehatan. Rineka Cipta. Jakarta.

Picauly I, Toy SM. 2013. Analisis Determinan dan Pengaruh Stunting Terhadap Prestasi Belajar Anak Sekolah di Kupang dan Sumba Timur, NTT. Jurnal Gizi dan Pangan. 8, (1), 55-62.

Rytter Mj, Kolte L, Briend A, Friis H, Christensen VB. 2014. The immune system in children with malnutrition-a systematic review. PLoS One. 9:e105017.

Suryawan N, Rakhmilla LE, Saragih SA, Amalia FF, Fitricia D, Jain ONA, Halimah HD, Faruqi FT, Pambudi MAS. 2019. Efektivitas Penyuluhan Pencegahan Thalassemia di SMPN 1 dan SMPN 2 Tempuran Kabupaten Karawang. Dharmakarya, $8,(1)$.

UNICEF. 2013. Children with disabilities. New york: UN Children's Fund.

Walker SP, Chang SM, Powell CA, SimonoffE, GranthamMcGregor SM. 2007. Early childhood stunting is associated with poor psychological functioning in late adolescence and effects are reduced by psychosocial stimulation. J Nutr., 137: 2464-9.

WHO. 2014. Global Nutrition Targets 2025 Stunting Policy Brief. Geneva: Switzerland. 